\title{
1. States as basic units
}

\section{THE NEED FOR AND ESSENCE OF BASIC UNITS}

Various theories focus on explaining what the State is for and how central it is in international affairs. The State being both the primary and principal subject of international law and the basic unit for the purposes of international relations expresses State autonomy and its lack of subjection to any external authority. This factor is of significant practical importance because no policy planning or prediction will make sense without an understanding of the range of units that can express their will and make autonomous decisions.

'Basic unit' means a qualified and eligible unit. In any sport, the actions and influence of the real world come into play in every game - the audience can cheer, sponsors can make a financial contribution, games can be fixed; but it still takes the players on the pitch to score a goal or pass the ball. It is the teams that win or lose the game, and it is their balance sheet on which that win or loss is recorded. The nature of basic units is thus anchored in the system in which the games take place; the system determines whether and how any power-political agenda will succeed.

The ontological enquiry on the essence of basic units is focused on their being - not on their material being, but on what makes them basic units. In this sense, the 'black box' or 'billiard ball' concept of basic units' is most suitable for understanding the essence of States from an interdisciplinary perspective, because it emphasizes their basic autonomy, as opposed to other qualities such as good behaviour, alignment, suitability or rationality. What is inside the black box cannot be externally determined; the way in which the billiard ball rolls is up to the State's autonomously determined policies. Only this concept of basic unit can have currency across the interdisciplinary divide and correspond to the legal concept of the autonomous State which can be bound only through its own consent. Albeit that manipulation, pressure and conformism on the inter-State plane are not unheard of, the above basic element of auton-

\footnotetext{
1 J.D. Singer, 'The Level-of-Analysis Problem in International Relations', 14 World Politics (1961), 77 at 81.
} 
omy and singularity informs both the legal and political concepts of the State; and the latter cannot be one thing for international law and something else for international relations.

If the reality of basic units is a system-level element, ${ }^{2}$ then in the conditions of international anarchy, basic units are those whose basic unit status has not been determined by any positive enactment or determination, and could not be abolished without transforming international anarchy into anything else. Even under the liberal view that the State is merely a tool to promote higher aims relating to the human condition, overlooking the nature of basic units could not be sensibly proposed - if only because the certainty about units that would be judged and held accountable would still be required. Otherwise, a radical redefinition of international relations methodology would be required to address relations among qualitatively different State and non-State units that have diverse internal cohesion, autonomy and power mobilization capabilities.

\section{KEY ESSENCE OF STATES AND METHODS OF ITS COGNITION}

Legal doctrine has long used the concept of legal personality to describe units that form part of the international legal system. Pufendorf has suggested that moral personality is attached by law to both individuals and associations; and by virtue of that, both have the essence of unity (einheitliche Wesenheit). ${ }^{3}$ A legal or moral person is a singular entity that can express will and participate in legal transactions. However, legal (or moral) personality cannot explain the difference between a State and other corporate entities, because the single concept of corporation, union or association can be applied to all types of human associations - whether private corporations, particular organs within the State, local communities, churches, universities or States themselves. For the purposes of international law, States have a qualitatively different kind of international legal personality which enables them to act within the international legal system, and which the State possesses and other units do not. This kind of legal personality refers to a unit's suitability to undertake multiple tasks or functions, such as treaty making, diplomacy or war, as the international legal system expects its basic units to do. A unit that has no such legal privileges cannot be a basic unit from the viewpoint of international relations.

Statehood implies not only the exercise of public authority (which historically has also been available to municipal, feudal and religious authorities), but also the autonomous ability to define the relevant society's public good

See K. Waltz, Theory of International Politics (1979), 43.

See O. von Gierke, Genossenschaftsrecht (Bd 4, 1913), 418. 
and hence supremacy over all entities within the State's internal realm, and non-subordination to any other external entity. It is inherent to the concept of State that any public authority not derived from the State legal order will be absorbed into it, and any public authority exercised by a non-State entity will be derived or outsourced from it. This has been the case internally with the suppression of feudal authority and with authority outsourcing patterns from the East India Company to modern private security companies; and externally with the establishment of international organizations through agreement between States.

For a State to determine the public good and regulate the life of a community, it must be a single, total and unified legal order. ${ }^{4}$ The autonomy of States and the totality of their legal order inevitably go hand in hand. There can be no more than one total legal order regulating social life in the same time and place. State legal order is self-contained and self-sufficient - not in the sense of the relevant society not depending on imported goods or services, but rather in the sense of the State operating its own legal order autonomously. Any dependence on foreign power is a matter of degree; while autonomy and independence are static concepts, manifesting the absence of the State's legal dependence on any other entity or authority, save to the extent of obligations assumed through its autonomous consent.

Gierke clarifies that any definition of 'State' is bound to include the aims of a community of people that live together, and sovereign and supreme public authority through which those community aims are realized. And sovereignty distinguishes it from other related communities or unions. ${ }^{5}$ But the elements to which Gierke alludes are multiple and qualitatively different from each other. It is possible for particular theories to prioritize some of these elements over others.

The theories used to explain the essence of a State include natural law, social contractarianism and organic theory. Historically, the natural law theory of the State - predominantly as a secular theory - could be deployed towards the policy agenda and aims of different interest groups; ${ }^{6}$ either to justify State excesses as a divinely ordained form of governance or as one representing a transcendent or superior public good, or to censor it out of transnational interest or ideology, depending on one's view of the content of natural law.

From the outset, the natural law view of the State has been premised on the thesis that the social contract founding the State left some individual rights

4 This classification is owed to H. Kelsen, General Theory of Law and State (1949), 377.

5 Gierke (n 3), 285-86.

$6 \quad$ See Gierke (n 3), 276-77. 
intact, and thus that the sovereign State operates as against sovereign individuals. $^{7}$ This contractarian attitude views the State as relative to some more foundational political consensus operative within the national society or on the transnational plane. A particular natural law vision could then suggest various versions of transnational consensus as to what being a State (or a good State) means, providing, as it were, an empty box to be filled with various items relating to economic and political freedom, ideology, treatment of minorities and so on - to judge whether the State's internal arrangement or policies correspond to some international measure or ideal. But on the plane of relations between States, this approach is hardly practicable, because international legal practice endorses conditional recognition of the State only in very limited circumstances, and statehood is independent of recognition anyway. ${ }^{8}$

Organic theory refers to historic and social factors - to certain immutable social and historical realities that determine the essence of States as frameworks within which peoples and nations live and develop, and which regulate their lives. Gierke speaks of historical-organic theory as an alternative to natural law theory, and of the State as the embodiment of national spirit (leibliche Verkörperung des Volksgeistes) and organic structure; the spiritual-moral order of life of the highest order; a unity in self-motion (organisches Gebilde, ein geistes-sittliches Lebewesen höchster Ordnung; ein sich selbst tragendes einheitliches Ganze). ${ }^{9}$ And if the historical theory of the State is not a mainstream explanation, it still tells us what the core thesis of the organic theory is: namely, reference to things that are a product of natural reality and are not arranged through human design and intervention.

A socio-historic reasoning could be just another version of natural law reasoning - one informed by considerations that refer to socio-historic realities rather than transcendent natural reason. The organic and natural law theories of the State are not that distinct from each other in terms of the possibility for their use both in support of and against the thesis that the State is a unique social union, superior to other social unions.

The initial point of reference of organic theory is a biological organism. According to Gierke, organic theory regards the State and other unions as social organisms and argues for the primacy of the overall organism over individual organisms (das Dasein von Gesammtorganismen, deren Theile die Menschen sind, über den Einzelorganismen). Social organisms or corporations

Gierke (n 3) 448.

8 See A. Orakhelashvili, Akehurst's Modern Introduction to International Law (2018), 100-101.

9 O. von Gierke, Die Germanische Staatsgedanke (1919), 22-23. 
are composed of heads and members; they have their own specific organization, functions and other structural divisions. ${ }^{10}$

The process of using organic theory in legal reasoning thus involves borrowing the initial concept from biology, applying it to sociological realities and then projecting ready-made legal concepts of positive law. However, biological organisms are inherently singular and are not composed by anyone's choice or purposive action, and their parts cannot exist without being part of the organism; while denoting social units and frameworks as organisms makes light of the divergence and differences that characterize such units and frameworks, containing organisms within organisms, as it were. Therefore, any blanket and indiscriminate application of the organic theory could risk obscuring ontological realities.

Organic theory was ancient and medieval in origin; but in more recent times, natural law theory found an ally to complete organic theory and present the State as an immanent organic whole, similar to a spirited body, characterized by the internal harmony of its parts and organs. The aim was to justify the primacy of the whole over its parts - whether by conservative or progressive writers centring on social contract conceptions. ${ }^{11}$

Gierke has explained that for Hobbes, society is an artificial creation, composed of individuals who are natural creations and living organisms. This was basically the same for Locke, Fichte and Rousseau: social organism as mechanically composed unity. This led to a genuine decrease in the net value of organic theory, because instead of observation of social unity alongside natural organisms and realities, emphasis was placed on artificially created frameworks of law and governance. ${ }^{12}$ The rationale behind this approach is that there are no organic social ties between people in the pre-State anarchy, or State of nature; so the State cannot be seen as a continuation of any pre-existing organic community.

Gierke explains that while organic theory was initially designed to explain monarchical absolutism, almost no political system escaped its influence. ${ }^{13}$ Organic theory elements can also be used for mechanic presentation of the State, ${ }^{14}$ especially as both organism and mechanism rely on a particular inner harmony: both describe ordered systems and predictable processes, whatever their origin. Precisely for this reason, Jellinek criticized organic theory as one of minor scientific value, because the very concept of organism with which it operates is derived from purposive institution and an 'organ' effectively

O. von Gierke, Das Wesen der menschlichen Verbände (1902), 13.

Gierke (n 3), 307-09.

Gierke (n 3), 445.

Gierke (n 3), 310.

14 Gierke (n 3), 310-11. 
means a machine. ${ }^{15}$ Jellinek suggested that the net effect of the organic theory is to state beliefs, rather than proving the existence of real social organisms. It works with analogies and thus cannot provide us with any genuine cognition of the relevant social phenomena. Hence, Jellinek thought that organic theory should be completely rejected. ${ }^{16}$

Relationship between State and society can also raise issues of organic theory. State and society coincide spatially. However, society is an organic, natural, instinctive phenomenon; while the State, as Jellinek explains, is an artificial organization, created, directed and operated through human will. ${ }^{17}$ However, even if the State is a mechanism, its representation of public interest and human needs dictates that it is organically inherent to human societies to have States, because otherwise they can have no ordered life or protection. While a particular constitutional arrangement within a State is a mechanism operated by or for the people, and hence a variable, the fact that there must be a State as a system of public authority or there will be no ordered human existence certainly amounts to an organic reality and a constant. Thus even if, on Hobbesian terms, the State is a mechanism, human societies still have an organic need to exchange obedience for protection from a public authority and to live under State rule. Particular forms of State may be arranged through human design; but the fact remains that no human community is possible without a State.

Society, on the other hand, is organic, not man-made; and so are some of the ways in which it influences the State and contributes to the formation of its will. It is not inherent to any State to adopt political repression or an economic policy of a particular kind. Instead, it is up to social forces to determine how far they will use the State to those ends, just as human will can mobilize the energy of a mechanical engine in a way that modifies the net effect that gravity or inertia would otherwise have.

As Erich Kaufmann's comprehensive survey of the development of organic theories of the State illustrates, an organic view of the State and society may be adopted to show that the State reflects deeper social perceptions and unity within a nation; or to critique the State; or alternatively, to view the State as a tool to promote further social development of the State $^{18}$ - in a way, remi-

\footnotetext{
G. Jellinek, Allgemeine Staatslehre ( ${ }^{\text {rd }}$ ed, 1914), 157.

Jellinek, 153.

'... nicht um unbewusst-organische, sondern um bewusst-willkiirliche Vorgange handelt es sich beim Dasein und Wirken der staatlichen Zwangsgewalt'; Jellinek, id,

18 E. Kaufmann, Über den Begriff des Organismus in der Staatslehre des 19. Hahrhunderts (1908).
} 221. 
niscent of Jeremy Bentham's utilitarian view of the State and government, or indeed any possible natural law outlook.

It is clear from the above that organic theory bleeds into ontology and asserts the singularity and unity of social frameworks. In order to escape false analogies, organic theory must denote as organic only those social phenomena whose singularity and materiality are just as real as the existence of biological organisms. This the organic theory does on both ethical and ideological grounds.

One way in which the application of organic theory to sociological phenomena could be challenged is illustrated in the reasoning of Marsilius of Padua, and in particular his theory of 'oneness': there can be unity of order which is not absolute unity, but which comprises a plurality of persons; a part can operate in certain ways, but the whole operates in its own way - a way in which a mere part cannot operate. A soldier who belongs to an army is a separate entity, but cannot fight a war, which is rather fought by the whole army. The State is not a natural unity. National society is not 'any oneness formally inherent, nor through any oneness permeating them or containing them like a wall' ${ }^{19}$ It could, however, be retorted that man cannot survive without living in a State. This way, the organic view could be yet another subset of perceptions and preferences as to what the State should or should not be.

What is endorsed here, however, is a more viable and narrower use of organic theory that reflects ontological realities and aims to determine the nature of the State by reference to its qualities and properties. The autonomous nature of the State is an organic constant, while a particular form of constitutional government is a variable. This way, organic theory can be removed from the realm of natural law reasoning, brought closer to ontology and then used more suitably to explain what the State is.

The human condition is a very broad notion and can raise questions as to whether political communities merely reflect that condition or positively shape it; and whether government must operate for the people or by the people, and can be informed by attitudes that prefer individualism and human autonomy to utilitarianism, which also professes to serve the human condition. The key element of Benthamite utilitarianism indeed is that, in order to serve the human condition, the State must adopt policies that yield the greatest happiness for the greatest number - even at the expense of the individuality of people who constitute a minority. The social contract theory could also be used to rationalize any such possible meaning of political communities. And while for those who are satisfied by the existing political and economic system, that social

19 Cited in E. Lewis, 'Organic Tendencies in Medieval Political Thought', 32 APSR (1938), 849 at $857-58$. 
contract would be premised on liberal ideas of political participation, for those who are not so satisfied, it would resemble more of the Hobbesian subjection contract. This, then, would prompt queries as to whether and to what extent the social contract reserves the right to resist. And as the fact of the adoption of the social contract and the text containing it cannot be identified, any possible content could be identified only through natural law deductions aimed either at defending existing constitutional systems or justifying resistance to them. In short, any particular ideology could interpret the terms of that presupposed social contract in a way that is consistent with that ideology. Consequently, any allusion to 'human condition' in a wholesale and pristine sense could simply be using this as a means to an end.

Any relevant perception of public good could justify the utility calculus to explain society's domination over an individual by the former's representation of the multitude of individuals, and their wills and interests. ${ }^{20}$ Organic theory could also be used to arrive at different ideological conclusions. Medieval political theory was organic in the sense of conceiving public institutions as representative of human nature and values; but it was not organic in a sense 'which conceives that the whole has a purpose distinct from and superior to the ends of individuals'. ${ }^{21}$ Modern liberal individualism differs from that original medieval individualism and empowers the individual rather than a social organization of individuals. ${ }^{22}$

Even the liberal democratic form of government does not do away with the role of the State in regulating all areas of social life and determining the meaning of the public good, subject to a limited set of constitutional rights that varies from country to country. The constitutional provision of individual rights can take place only through the State's recognition. A liberal State as a legal order is just as autonomous as any other; its rules are just as binding on dissenting parts of society; and resistance to government is just as unlawful as it would be in any tyranny or dictatorship.

Ruling autonomously over the ruled people is a key element of democratic as well as tyrannical government. Even if people's will is reflected in elections and majority votes, there are still situations where turnout in elections is low. In those cases, elected State organs are not bound by the electorate's wishes; instead, they interpret these themselves and formulate policies as to what to do about them. Even if a political party promises low taxes to the electorate, gets elected and then increases taxes and is voted out a few years later, that tax

20 Lewis, at 855.

21 Lewis, at 876.

22 Lewis, at 863. 
legislation still counts as State will and law. The reflection of any version of natural justice or societal will is not essential to the legal essence of a State.

\subsection{Purposive or Justificatory Views of the State}

This idea has been most eloquently expressed in social contractarian terms that 'a state's claim to autonomy in this sense rests on the conformity of its institutions with appropriate principles of justice'. ${ }^{23}$ When subsuming the examination of all relevant theories of the justification of the State, Jellinek concluded that all of these theories deal essentially with the justification of one single element of States - their public authority - as the tool used to govern, prevail over and in some cases even destroy individuals. ${ }^{24}$ The ethical and justificatory view of the State is inherently different from a focus on its autonomy. However, as with human beings, telling States what is good for them and their autonomy to decide what to do amounts to a contradistinction. Virtue, wisdom, prudence and ethics can inform laws and policies that the State adopts; 'autonomy' refers to the State as a singular entity that decides independently from internal and external constraints.

In principle, all social institutions, communities, corporations and religious institutions could be justified or critiqued from some point of view. Aristotle has suggested that the State has natural priority over other kinds of associations because individuals have a natural impulse to unite in State association. ${ }^{25}$ To Aquinas, the State is a 'perfect community' which can satisfy the necessities of life and hence become politically autonomous. ${ }^{26}$ To Hobbes, States are independent and in a state of nature in relation to one another; yet because they uphold the industry of their subjects, the latter are spared the misery they would suffer in a state of nature and complete liberty. ${ }^{27}$ The singularity of the concept of the State as a basic unit that determines and enforces public utility and provides orderly government and life to people is the same for Hobbes, who denies that international law exists; and Vattel, whose writings have given authority to the needs of those working in international law for many decades, if not centuries. As a summary of various theories shows:

To the question "Why the state?" there are many answers: because it is an indispensable condition of value; because it is currently the best vehicle for achieving 
the welfare of humanity; because it is the best approximation of a "comprehensive" community; because it is the most effective guarantor of rights; because it expresses the freedom of a self-determining group; because it rests on a contract; because it is part of a system of legal authority; or because it is useful from a tactical viewpoint in securing a world communist society. ${ }^{28}$

All of the above ethical views are premised on a degree of loyalty to the State. For Hegel, the State's internal arrangement and legitimation provide it with its individuality and thus make it a sovereign entity. ${ }^{29}$ Lasson has also adopted the Hegelian stance: the State legal order embodies the purpose of a nation. The will of the State has its internal limit only in terms of the certainty of its purpose (Bestimmtheit seines Zweckes); and it extends to anything that could serve that purpose, without any spatial limitation (im ganzen Umkreise der Natur). ${ }^{30}$ Thus, the internally defined State purpose produces the will, which can act without external restrictions. Lasson went on to explain that the sovereign State is a purpose of its own, unlimited with regard to anything that surrounds it (ungebunden und unbeschränkt mit Bezug auf alles was ausser $i h r$ vorhanden ist) and independent from any external law or will. Otherwise, Lasson argued, the State would be deprived of the possibility to develop itself in the direction that its individuality requires, and consequently would not be free. ${ }^{31}$ Lasson developed this internal justificatory theory of the State to aid what Hobbes described in a more structural manner: the absence of a sovereign to impose law on States.

The liberal view is that 'States represent the demands of a subset of domestic individuals and social groups, on the basis of whose interests they define "state preferences" and act instrumentally to manage globalization'. The State:

constitutes the critical "transmission belt" by which the preferences and social power of individuals and groups are translated into foreign policy. In the liberal conception of domestic politics, state preferences concerning the management of globalization reflect shifting social demands, which in turn reflect the shifting structure of domestic and transnational society. Deriving state preferences from social preferences is thus a central theoretical task of liberal theory. ${ }^{32}$

28 T. Nardin, 'Convergence and Divergence in International Ethics', in T. Nardin and D. Mapel (eds), Traditions of International Ethics (1992), 297 at 321.

29 G.W.F. Hegel, Grundlinien der Philosophie des Rechts (1911), 261.

30 A. Lasson, Princip und Zukunft des Völkerrechts (1871), 12-13.

31 Lasson, 22.

32 A. Moravcsic, 'The Ethics of the New Liberalism', in C. Reus-Smit and D. Snidal (eds), Oxford Handbook of International Relations (2008), 234 at 237. 
Waldron suggests that States 'are not ends in themselves, but means for the nurture, protection, and freedom of those who are ends in themselves'. ${ }^{33}$

It is correct to say that the liberal theory stands in stark contrast to Hobbesian or Hegelian explanations of the State insofar as the domestic constitutional arrangements of a State are concerned. When applied to international relations between States, however, this liberal theory of the State could be just another way of asserting the individuality and substantiality of States on Hegelian terms. The dedication of States to 'those who are ends in themselves' may also inform a perception of their individuality accordingly and a consideration of them as liberated from external normative restrictions. Whether the State is seen to exist for its citizens or the other way around, the State can still be a basic singular unit, free of external restrictions and guided by its own domestic concept of public good and utility, whatever that might be. The 'social preferences' to which Moravcsik alludes are ones of domestic constituents; ones that any utilitarian or Hegelian account of a State would be happy and comfortable to operate with.

The rise of modern liberal doctrine coincided with Fukuyama's celebration of the triumph of the 'ideal State' at the end of the Cold War, and of the fact that liberal capitalism was unchallenged as a model of good life. On Fukuyama's account, historical progress has determined that this form of government is the ultimate destination of the human race. National and cultural differences are no barriers to that. ${ }^{34}$ But as for Hegel, prevailing in the struggle between the forces of history entitles the State to export its own life externally and thus contribute to the externalization of universal spirit. The world spirit (Weltgeist) that thus emerges constitutes an absolute right (absolutes Recht), and a nation externalizing its spirit internationally becomes a dominant nation. ${ }^{35}$ Overall, Fukuyama's view of the State reflects his broader thesis of the 'end of history', which he deduced from the end of the Cold War.

It is unclear whether the overall essence of the liberal view of the State can be divorced from the utilitarian thesis that its political order ought to be obeyed because it provides people with freedom, prosperity, law and order and other public goods. Both monarchies and republics, tyrannies and liberal democracies, can be seen as organic expressions of a society composed of individuals. A particular form of oppression, inequality or injustice can always be justified by alluding to the greatest happiness of the greatest number. And

33 J. Waldron, 'Are Sovereigns Entitled to the Benefit of the International Rule of Law?’ 22 EJIL (2011), 315 at 325.

34 S. Burchill, 'Liberalism' in S. Burchill, A. Linklater, R. Devetak, J. Donnelly, M. Paterson, C. Reus-Smit and J. True (eds), Theories of International Relations $\left(3^{\text {rd }} \mathrm{ed}\right.$, 2005), 55 at 56.

35 Hegel, Rechtsphilosophie, 271-73. 
this need not be the extreme forms of oppression for which totalitarian States are known; it can also refer to the number of State citizens who are imprisoned or incarcerated, who live in poverty or who are inadequately educated. And even if the legal constitution of a State does not expressly require or mandate a particular pattern of oppression or discrimination, social stratification or privilege, organic theory can still be used to explain how the existing constitutional and political system preserves or leaves intact all those social divisions - again at the service of the utilitarian public goods that the State prioritizes over competing aims.

Gierke explains that the natural law theory endeavours to set limits on the rationality of positive law arrangements and thus presupposes a transcendent rational ideal that might be unachievable, but should be approximated as far as possible. ${ }^{36}$ The essence of justificatory theories is a particular ethical standpoint that invariably characterizes each such theory. The reliance on the public good may be seen as apologetic of the existing legal system; or alternatively, as liberal critique of good and bad States. Kelsen observed that: 'Nothing can show more clearly the futility of the dialectic method than the fact that it enables Hegel to praise the state as a god, and Marx to curse it as a devil., ${ }^{37}$ According to various theories or ideologies, the State may be seen as an ultimate good or as an ultimate problem; but even where it is seen as an ultimate problem from a liberal or libertarian point of view, it is still (and invariably) a tool and mechanism used constructively by the relevant society to maintain social order, which could be justified only from the utilitarian point of view that people and their activities need protection, and that the State is therefore a superior value which the individual ought to obey and submit to. But what if particular individuals or their groups are not satisfied with the protection and obedience calculus that the State constitution endorses? How then could any purposive theory - whether liberal, Hegelian or utilitarian - be said to be on the same side as people; unless only a voting majority counts as people and minorities numbering in the millions do not count as such?

Even in Western democracies, no single approach can be identified as regards the adequacy or acceptability of the extent to which the State respects individual liberty - for instance, with regard to issues of major importance such as racial hate speech, gun control or the death penalty. Or take the case of extreme poverty in the United States, ${ }^{38}$ which - complemented by the overall

Gierke (n 3), 284-85.

37 H. Kelsen, 'The Natural-Law Doctrine before the Tribunal of Science', 2 Western Political Quarterly (1949), 481 at 513.

$38 \mathrm{UN}$, Report of the Special Rapporteur on extreme poverty and human rights on his mission to the United States of America (Philip Alston), A/HRC/38/33/Add.1, 4 May 2018. 
proportion between the entire American population and its voting population - would at least provide serious grounds to reflect on whether, under any utilitarian theories - including the liberal one - the United States is a good State or a bad State. But none of this would lead to a denial of the fact that in any case, the United States is a State.

\subsection{Juridical View of the State}

The autonomy or centrality of States as basic units in international affairs cannot be deduced from their domestic constitutional arrangements or their political and ideological priorities. It must rather be identified according to juridical criteria which internationally serve as the measure of State legitimacy. A State can be defined only legally (as an arrangement that meets certain criteria or has required qualities or properties), and not politically (as an arrangement that is preferable or desirable). From a purely scientific view, the crucial reality of States consists of the fact that they rule over certain territory, are autonomous and possess the highest level of legal authority over people; hence, they are externally independent, through which any national power can be mobilized and any national interest entertained or implemented.

The legal positivist theory of the State suggests that the State is a legal order in existence and operating efficaciously. Autonomy is the State's inherent characteristic, regardless of which pattern of internal or ideological justification it adopts. The positivist view does not query whether the State is a supreme good or a necessary evil, because it can be either of them only because it maintains an autonomous legal order of its own.

The analytical history of States being viewed as singular basic units - a discourse on the essence of all States, rather than the justification or censuring of a particular State - is longer than it may appear at first sight. Gierke explains that it was the doctrinal recognition of the relevance of the modern State that made jus gentium relate to international law as law applicable between sovereign States. The legal philosophy of Grotius centred on the State, encompassing its internal and external relations alike. ${ }^{39}$

However, doctrine was very slow to embrace this need. After Aristotle, initial insight was provided by Bartolus, who regarded States emancipating in their autonomous status during the protracted demise of the Holy Roman Empire as communities that did not recognize a superior authority (соттиnitas superiorem non recognoscentes), or perfect political communities. As Canning explains, Bartolus' representation of the will and consent of the people endows a political entity with the status of populus liber and entitles

\footnotetext{
39 Gierke (n 3), 277, 283-84.
} 
it not to recognize a superior authority. ${ }^{40}$ On this account, the State's internal constitution is irrelevant; its factual existence as an independent unit is more important. However, it is suggested that Bartolus' theory on the independence of States was partial and fragmentary, because he was concerned only with city-States and their independence from the Holy Roman Empire, not with kingdoms (and not even with Italian ones). ${ }^{41}$ Still, with regard to those States, Bartolus did elaborate on the core essence of independent statehood. Canning suggests that:

To indicate the complete independence of such a city Bartolus produces his juristic masterstroke by attributing to it within its territory the same powers of jurisdiction which the emperor enjoys in the empire as a whole: it is a civitas sibi princeps (city which is its own emperor). ${ }^{42}$

But the consent - popular or otherwise - to which Bartolus refers is consent in a rather peculiar sense, probably signifying popular toleration of the ruling political system; it is certainly not legal consent. If it were, it would not be describing whatever was happening in fact. And it is still the case that Bartolus 'provides a juristic justification for the legal sovereignty of the independent Italian cities as it actually existed'. ${ }^{43}$

Among the classical writers, Grotius has articulated the framework concept of the State as a basic unit in international relations, rather than affiliating it with a particular pattern of constitution or relationship between rulers and the people within a particular State. As noted correctly, Grotius 'lays no such stress on the contract as the anti-monarchic writers of the generation before him or as Hobbes and Locke in the succeeding generations'. ${ }^{44}$ What approximates Grotius even closer to the juridical view of the State is his comment that, while in most States governments operate for the benefit of those who are governed, this is not a precondition of the government as such, but rather a choice made by particular governments in particular cases. ${ }^{45}$

\footnotetext{
40 J. Canning, The Political Thought of Baldus de Ubaldis (1987), 96-97.

41 C.N.S. Woolf, Bartolus of Sassoferato: His Position in the History of Medieval Political Thought (1913), 109-10, 112.

${ }^{42}$ Canning, 96-97.

43 Canning, 97 (emphasis added).

44 W.A. Dunning, A History of Political Theories from Luther to Montesquieu (1933), 181; the same could be said of Lauterpacht's point that Grotius rejects raison d'etat by silence - Grotian Tradition, 30 .

45 H. Grotius, 'Law of War and Peace', J.B. Scott (ed), Classics of International Law (1916), 109-10.
} 
Kingsbury has suggested that Grotius did not have a clearly defined concept of the State. ${ }^{46}$ However, Grotius' take on the legal essence of the State is robust and coherent. Having scrutinized unions such as family and corporations, Grotius suggests that the State has a distinct role in ensuring the public good and utility. It is:

An association in which many fathers of families unite into a single people and State gives the greatest right to the corporate body over its members. This in fact is the most perfect society. There is no lawful act of men which does not have relation to this association either of itself or by reason of the circumstances. ${ }^{47}$

This is a 'a single essential character' of the State; ${ }^{48}$ and sovereignty resides with one that is not subject to legal control. ${ }^{49}$ Grotius further described the State as a 'most perfect society', the 'full and perfect union of civil life, the first product of which is sovereign power' - the bond that binds the State together. ${ }^{50}$ Grotius regards sovereignty as part of the entire State itself, rather than of particular organs that have a pre-eminent constitutional position under the form of government which the State has adopted. ${ }^{51}$ In particular, this element of the State as regulating each and every aspect of individuals' lives shows an early anticipation of the idea of the State as a total legal order which was developed as part of Kelsen's pure theory of law.

Grotius comes closer to a singular view of the State from the legal perspective, independently of the injustice or otherwise of its policies. The State as public authority operates through its legal system:

A body that is sick is nevertheless a body still; and a State, although seriously diseased, is a State so long as there remain tribunals and the other agencies that are necessary in order that foreigners, no less than private citizens, in their relations one with the other may there obtain their rights. ${ }^{52}$

Further divorcing the essence of States as basic units and like units from their domestic constitution and policies, Grotius also denies the right to resistance; but that is merely to say that under the domestic law of the State, there is no

\footnotetext{
46 B. Kingsbury, 'A Grotian Tradition of Theory and Practice?: Grotius, Law and Moral Skepticism in the thought of Hedley Bull', 17 QLR (1997), 3 at 14.

47 Grotius, 253.

48 Grotius, 310-11.

49 Grotius, 102.

50 Grotius, 253, 311.

51 Grotius, 314.

52 Grotius, 632.
} 
such right. And whether royal authority is revocable by the people seems to depend on the domestic constitution. ${ }^{53}$

With Kant and Rousseau:

there is no wavering in the assumption that man lives and always will live in a separate state. This is their starting-point with man and here, not in some wider human community, are the roots of his being. Though they begin with man, they do not begin with mankind and inquire into the reason and unreason of the separate states into which he is divided. They simply take man's membership of a separate state as the primordial fact. ${ }^{54}$

Montague Bernard has observed that even the worst government provides a version of public good and legal order to its people, whose benefits outweigh the evils attendant to oppression and exaction. ${ }^{55}$ Martin Wight also explains that:

As well as with the founders of international law, for the Machiavellian too, international society is a society of perfect societies, because the state is the final term of political organization. This is not Hegelianism, but a matter of fact. The state is the body that affords the protection and organizes the welfare of its members. The majority of states today may well be tyrannical or corrupt, but would not the inhabitants of every state be worse off if that state dissolved altogether? ${ }^{56}$

As examples of this, Wight refers to the collapse of State machinery in Lebanon and Uganda decades ago; the more recent example of Somalia could also be invoked. That law and order cannot be secured without the State (and hence the State being law and order itself) is an ontological reality that cannot be escaped, not an ethical justification that may be accepted or rejected.

The modern legal concept of the State that can be used across the interdisciplinary divide, rationalizing the State as a basic unit in world politics and as an international legal person, was refined and consolidated by Karl Ludwig von Haller, in terms of both the robustness of this basic concept and the originality of its presentation, and its lasting importance - regardless of Haller's somewhat conservative outlook, which might have informed its formulations. Capturing the ontological aspects of this problem, Haller proposed that the definition of a State be based on independence, which is the basic feature of all States; and not on State purposes, which differ from State to State. ${ }^{57}$ Most

Grotius, 114-15, with examples discussed; against resistance, see id, 138 .

54 M. Donelan, 'The Political Theorists and International Theory' in M. Donelan (ed), Reason of States (1978), 75 at 76.

55 M. Bernard, Four Lectures on Subjects Connected with Diplomacy (1868), 180.

56 M. Wight, International Theory: The Three Traditions (1992), 139-40.

57 K.L. von Haller, Restauration der Staats-Wissenschaft (1820), 467. 
States have no purpose anyway, except to enable the authorities operating under their constitutions to enact and implement laws and policies.

Haller has explained that being a State is contingent not on any particular degree of freedom that it accords to the people it rules, but rather on its ability to determine the extent to which such freedom is accorded. In the spirit of his times, he suggests that the State is a complete union of free persons and servants (ein vollendeter Verein von Freien und Dienstbaren) - a regulatory framework; not a mirror image of existing societal perceptions of public good, freedom and justice, which according to Haller are rather vague concepts and stand open to abuse. The State is not the realization of a particular idea of justice or utility; instead, it is the framework that determines what these ideas are and realizes them in actual life. ${ }^{58}$

Independence from other earthly powers of the ruler of a monarchy or republic is what makes it a State, ${ }^{59}$ because there is no universal meaning of policies such as prosperity, freedom, sociability, morality, enlightenment or economic development; everyone has their own view of those. ${ }^{60}$ Thus, the State is constituted not by public opinion, but by constitutional authority, which then determines what the public good is.

Haller says that all other corporations can have their own systems of laws, regulations and adjudicatory, disciplinary and enforcement powers; but the State is still distinct. The State is not simply a legal person or a voluntarily or artificially created union; but rather a self-existent social union (für sich selbst und durch sich selbst bestehendes, geselliges Verband),${ }^{61}$ emphasizing the independence of the ruler or head of State (Fürst, Oberhaupt), somewhat similar to Austin's sovereign.

It has been common to assert, with regard to both monarchy and republic, that a plurality of rulers is not inconsistent with the unity of a directing will that diverse social interests within that society could not provide. ${ }^{62}$ Hegel would say that the State is legally superior to individuals because of its purpose; while Haller says that it is superior regardless of its purpose.

Haller's approach is in line with the emphasis by Hobbes on the unity of the representer, not of the represented, which makes a person 'one'. ${ }^{63}$ This unity of State legal order is not an obstacle to developing a constitutional system of government, but rather a precondition to it, because only the State adopts and

\footnotetext{
Haller, 465.

Haller, 474-75.

Haller, 468.

Haller, 463.

Lewis, at $857,867$.

63 Hobbes, 106.
} 
operates the constitution and guarantees constitutional rights and status to all relevant entities within its realm.

Georg Jellinek suggested that the legal method is used not to explain the material essence of the State, which he thought would interfere with what other disciplines do; but rather to make the State juridically conceivable. Jellinek explained that protagonists of the 'real' and empirical State essence have also tried to constitute it as the juridical essence of the State. ${ }^{64}$ The correct explanation of the State is one that explains its unity. ${ }^{65}$ Justification theories can never be properly ontological; they are bound to incorporate ideological and ethical elements. They can only rationalize that the State looking after public life is a good thing; but not any generally accepted view of the extent of State rights domestically or internationally, or whether the State should be self-sufficient or subject to a particular ideology that is intent on either justifying or censuring the particular State and its constitutional system.

The analytical acuteness of this problem notwithstanding, even in Jellinek's classic treatise - containing the most detailed, comprehensive and sophisticated analysis of State aims and justifications - there is no attempt to identify a legal or positivist basis from which the derivation of State authority, as opposed to its justification, could be rationalized. ${ }^{66}$ That position persisted until Kelsen emphasized the identity of a State with an efficacious national legal order, as opposed to its justification or aims, on neutral terms; and its consequent rationalization of the basic norm of the relevant legal order, which in turn determines the identity of that legal order.

Kelsen's approach corresponds to the opinion of Grotius that 'law... exists in a State just as the mind in the human body; for when this is taken away the State ceases to exist'. ${ }^{67}$ Vattel is similar to Grotius on this point, observing that legal authority constitutes and defines the State and makes it sovereign - thus

64 Jellinek, 163 ('Die juristische Erkenntnis des Staates will daher nicht sein reales Wesen erfassen, sondern den Staat juristisch denkbar machen, d. h. einen Begriff auffinden, in dem alle rechtlichen Eigenschaften des Staates widerspruchslos zu denken sind. Die Erkenntnis des realen Daseins des Staates muss diesem Begriff des Staates zugrunde gelegt, darf ihm aber nicht gleichgestellt werden. Die Gegner der "Fiktionen" in der staatsrechtlichen Wissenschaft haben versucht, das, was sie als reales Dasein des Staates behaupten, zugleich als das juristische Wesen des Staates zu konstruieren').

65 Jellinek, 163-64.

66 Instead addressing the normative power of the factual (the normative Kraft des Faktischen) as an aspect of the relationship between the State and society; Jellinek, 340-41.

67 Grotius, 632. 
also endorsing a singular view of the State regardless of internal organization or the nature of domestic political consensus or legitimation. ${ }^{68}$

All this prepares the platform for the concept of a State whose existence is premised on an efficacious legal order. Kelsen's description of the State as an efficaciously existing and operational order of positive law is transparent and generalizable to all States; it describes the organic reality and features of all States, among which autonomy is pre-eminent. On this account, the essence of the State can be comprehended regardless of its justification, goodness or badness.

When focusing on the State and its sovereignty, Kelsen questions the prioritization of such notions of statehood as give expression to underlying social and causal realities through which States function and operate. Kelsen upholds such rationalization of statehood as conceivable only from the juridical point of view - the State being an entity created by and operating through law. For only this conception of the State could explain its nature as an entity underived from any superior authority. ${ }^{69}$ Kelsen distances himself from the 'natural sciences' or the sociological explanation of authority and domination processes (Herrschaftsprozesse) within the State. For within the State realm, there could be other processes of authority and domination that are unrelated to State authority; or even authority and domination driven by a foreign State. Kelsen's key thesis is that factuality says nothing juridically (Die Faktizität sagt juristisch eben gar nichts). ${ }^{70}$

Kelsen speaks of the sovereign State as a legal order not derived from any other, while other associations are legally derived from the State's legal order. ${ }^{71}$ As the State is sovereign, all other entities form part of the State legal order. ${ }^{72}$ This is due to the fact that the State efficaciously exists and operates as a legal order without any superior authority. Most importantly, Kelsen's method enables us not only to distinguish between States and other corporations, but also to form a view as to where and how the sovereign (domestic) realm is delimited from the realm of another State or from the international sphere.

From this perspective, what is a State turns not on the forms of land ownership it allows, or the subjects its school curriculums include, or the extent to

68 E. Vattel, The Law of Nations or the Principles of Natural Law applied to the Conduct and to the Affairs of Nations and of Sovereigns in Scott (ed), Classics of International Law (Washington 1916), 11.

69 H. Kelsen, Das Problem der Souveränität und die Theorie des Völkerrechts, (2nd ed, 1928, reissued 1960), 9-10.

70 Kelsen, 71.

71 Kelsen, 13.

72 H. Kelsen, Allgemeine Staatslehre (1928), 108. 
which it allows freedom of expression or trade with foreign nations; instead, the State is a unit whose decisions are required to determine how all these activities are organized. Regardless of its form, each State government is a ruler, regulator and enforcer, through which processes it deals with the representation of domestic sectoral interests and determines what constitutes the public good on the national plane. The nature of the public good is not sufficient to work a robust concept of a State as a basic unit; and hence a purposive or justificatory view of the State is unscientific and ideological - it is meant to justify or criticize, not to explain or rationalize.

After all, sovereignty under international law includes the State's authority to determine its form of government autonomously. As long as a State operates efficaciously, it is capable of adopting a constitution that endorses any form of government on the spectrum from direct democracy to absolute monarchy, and of determining the extent to which it is controlled by the people. Within the single State legal order, sovereignty cannot be divided, for sovereignty is about sustaining the legal order in the first place; whether one particular organ within the State has absolute power or whether power is shared among various organs, there will still be a constitution and legal framework bestowing and validating that authority. If a State is identical to the legal order that it authors in its totality, then the State does not derive its authority and status from any other legal authority or prescription that is cognizable in any legal order other than that which the State itself authors. If, however, the State is more than the legal order it produces, then to that very precise extent, it will not be cognizable under the very same legal order that it creates.

\subsection{The 'Modern' State}

The singular concept of the modern State is indispensable for affording a coherent concept of basic units in international affairs. Vattel has suggested that, just as dwarves and giants are both persons, so small and large States are States alike. For an interdisciplinary analysis of international affairs, a similarly unitary model must be adopted - one of a State that can have autonomous will and undertake international obligations, engage in war, authorize foreign trade, extradite criminals and receive envoys. Venice, France and the Ottoman Empire were all States, regardless of the differences in size and organization. The equality of States and their identical status are natural consequences of the fact that there is no world government over and above States, and that the latter are autonomous in their mutual relations. States are basic units not because they can take political action or exert power, but because there is no earthly authority over them.

There has been extensive debate as to which entities in various periods of history would qualify to be described as a 'modern State' - whether ancient 
Greek city-States, medieval Italian city-States, States with a broader territorial basis or empires. ${ }^{73}$ Much international relations theory has endorsed the thesis of the formation of modern States from the fifteenth century onwards, thus adopting a rather counterfactual Eurocentric attitude to international affairs. ${ }^{74}$ Hinsley suggests that the assertion by States of their independence from pope or emperor was not accompanied by an argument that they were sovereign. ${ }^{75}$ Sir Henry Maine has narrated how, after the demise of the Roman Empire, the first tribe sovereignty arose and subsequently competed with imperial sovereignty. ${ }^{76}$ In all of these cases, however, the successful assertion of independence from pope or emperor inevitably led to the relevant State becoming a sovereign State.

Sovereignty is a structural characteristic of basic units, which indicates the legal status and position of independent units across the globe; not a contribution of one particular region's political history. Mayall suggests that statehood is a European phenomenon exported to the world:

Whether or not it lacks indigenous historical roots in some parts of the non-European world, it has been successfully exported everywhere. And this success is now firmly rooted. It stems from the universal and enthusiastic acceptance of the Western theory of sovereignty. This theory has always been sufficiently elastic to accommodate a wide variety of regimes since, in the last analysis, only de facto control is regarded as proof of legitimate authority. No wonder that in the wake of Western imperial withdrawal the doctrine was embraced with such enthusiasm by leaders who were often short on legitimacy in their own societies. ${ }^{77}$

This thesis is rather self-defeating, because if statehood is just about the factual control and rule of relevant societies, why is it Europe-specific? On what account (other than one's preferred ideology) is it that States which developed in various non-European parts of the world from ancient times onwards cannot be regarded as States proper? And most importantly, the Eurocentric view of the State is a subsequent analytical or ideological imposition on an accurate understanding of relations between Europeans and the rest of the world over centuries, during which European States coexisted, cooperated and fought with other States within the single context of a universal international system. ${ }^{78}$

73 See S. Elden, The Birth of Territory, 198.

74 B. Buzan and R. Little, "The Idea of "International System": Theory Meets History', 3 International Political Science Review (1994), 231 at 251.

75 F.H. Hinsley, Sovereignty (2 ${ }^{\text {nd }}$ ed, 1986), 167.

76 H. Maine, Ancient Law (1908), 106-07.

77 J. Mayall, 'International Society and International Theory', in M. Donelan (ed), Reason of States (1978), 122 at 130-31.

78 I cannot expand here on the merits and flaws of Eurocentrism; see instead A. Orakhelashvili, 'Unlocking the Unreal: An Inter-disciplinary Take on Hedley Bull's 
The nature of the State was better understood over centuries than Eurocentric accounts would suggest. On Sir Henry Maine's account, if sovereignty had not become a concept related to supreme authority over a defined part of territory, the theory of Grotius would have been inapplicable. ${ }^{79}$ Still, Grotius did not think that sovereignty and independence were qualities of European States only; like Vitoria before him, he refused to adopt a discriminatory approach with regard to European and other States. Wolff and Vattel endorsed the same approach; so the Eurocentric view of States did not have much currency.

And by then, sovereign and independent States had already existed outside Europe, such as Japan, China, Korea, Thailand, Turkey and Iran. They were never colonized, and maintained the same status and legal identity as European States. A down-to-earth look at historical realities easily demonstrates that ancient and modern States, territorial and city-States have invariably conducted their mutual relations by treaty, diplomacy or war; and the query as to the essence of a State is no more or less than a query as to which units have the status to engage in these activities.

The link between 'ancient' and 'modern' views of the State is reflected in the fact that the medieval rediscovery of Aristotle and his conception of statehood contributed to the view of the independence of territorial States as sovereign units from papacy and empire ${ }^{80}$ According to Kelsen, the formulation of ideas about the State was the result of a medieval intellectual struggle between ancient doctrines and Christian ideas, and the latter's influence in modifying the ancient concept of the State ${ }^{81}$ As Gierke explains, medieval political philosophy moved away from the ancient Greek and Roman designations of polis and civitas as autonomous units, and regarded as a State only the Empire, which was perceived to represent the organic unity of the world; individual States were seen merely as its provinces or communities. The absolute nature of State autonomy was redefined into relative autonomy, and therefore the qualities of the State were further considered to extend to sub-State corporations and communities. John of Paris and Bartolus objected to this approach, and suggested that the State knew no world empire above it. The difference between civitas, regnum and imperium was thus merely one of

Notions of "International Society" and "International Order", 14 Chinese Journal of International Law (2015), 15-55; A. Orakhelashvili, 'The Idea of European International Law', 15 EJIL (2006), 315-347.

79 Maine, 114.

80 P. Riley, 'The Origins of Federal Theory in International Relations Ideas', 6 Polity (1973), 87 at 100-101.

${ }_{81}$ H. Kelsen, Die Staatslehre des Dante Alighieri (1905), 17-18 ('Das Resultat dieses Kampfes bildet die Lehre vom modernen Staate auf dem Boden einer allgemeinen Renaissance der durch das Christentum geläuterten, modifizierten Antike'). 
size. Thus, in the Middle Ages, the State was already distinguished from other units via its sovereignty. ${ }^{82}$

The natural law view of political communities such as the Holy Roman Empire, and of the coexistence within each of multiple units that asserted their own autonomy, attempted to explain less the nature of basic units of international affairs and more the peculiar imperial framework of coexistence of those basic units. Although, as Gierke shows, the understanding of the modern State was informed by a revival of interest in and influence of Aristotle, who defined States - notably Greek city-States - as perfect communities, the natural law view of 'the ideal of the organic structure of the whole Human Race' required writers to develop a view of a multi-level political architecture within which cities were subject to kingdoms, which in turn were subject to the empire. Thus, a community of lower status would be subject:

to higher and wider communities in which it found its completion and its limitations. Thus, no sooner has the medieval thinker given his definition, than he is withdrawing it without the slightest embarrassment. His superlative becomes a comparative, and the absolute attribute becomes relative..$^{83}$

This relativization of the concept of the State was part of a political philosophy and political struggle not least driven by advocates of papacy and the Holy Roman Empire; but that could hardly alter the actual nature of the State. Kelsen observes that as early as Dante in the thirteenth century, the doctrinal foundations of the 'modern' State were revived. ${ }^{84}$ From the time of Bartolus onwards, 'The differences between civitas, regnum and imperium became mere differences in size instead of being joints in the organic articulation of a single body'. ${ }^{85}$ Grotius expressly stated that 'a state must be conceived of as something... "self-sufficient," which in itself constitutes a whole entity" - something autonomous, 'that is to say, possessed of its own laws, courts, revenue, and magistrates; something endowed with its own council and its own authority' ${ }^{86}$ This is another vivid illustration of the continuity of the uniform idea of statehood throughout various epochs of history.

82 O. von Gierke, Johannes Althusius und die Entwicklung der naturrechtlichen Staatstheorien (1902), 229-32.

83 O. von Gierke, Natural Law and Theory of Society (1934), 96-97.

84 H. Kelsen, Die Staatslehre des Dante Alighieri (1905), 21 ('zugleich aber lassen sich die ersten deutlichen Anfänge einer modernen Staatsauffassung erkennen, wie dies insbesondere bei Dante der Fall ist').

85 O. von Gierke, Political Theories of the Middle Age (1913), 97.

86 H. Grotius, Commentary on the Law of Prize and Booty (2006), 96 (Grotius refers to the ancient Greek view of Thucydides). 
Within the Holy Roman Empire, North German towns from the mid-thirteenth century were independent sovereign States and possessed powers of taxation, expenditure and possession of fleets. ${ }^{87}$ East Asian States have also been described as 'paradigmatic nation-States' whose State identity dates back further than that of European States. ${ }^{88}$ As Modelski observes:

Gradually the mechanics of the system made sure that nation-states became the rule: all other forms of political organisation were now exceptions - that is, 'pre-modern' or 'traditional' formations... successful states... would in fact conform to the same image. ${ }^{89}$

Haslam also explains that the notion of raison d'etat is applicable both to nation-States and to medieval city-States, ${ }^{90}$ as they all could form autonomous foreign policy and had authority over the relevant territories. It is further clarified that:

Whatever form a body politic may take, whether it be a tribe or clan, a "city state," a composite feudal system, a "church state," or a modern sovereign state, the capacity to engage in an armed contest with adversaries, reflected in a fundamental inner division of labor between military and other occupations, remains a constant characteristic. ${ }^{91}$

And, illustrating the continuity of a single and unified State concept, Modelski observes that: 'The nation-state not only shares some characteristics with the ancient city-state (such as classical Athens or Renaissance Venice) a state that is cohesive, well-organised and has continuity through time; it is, in one sense, a city-state writ large.' It is in this sense that, 'All in all, the nation state is the characteristic political structure of the modern world system. ${ }^{\prime 92}$

Ontological accuracy requires an acknowledgement that State and 'modern State' have always been the same thing.

87 F.H. Gareau, 'A Contemporary Analysis of the Hanseatic League', 47 Il Politico (1982), 97 at 103, 108.

88 T. Ginsburg, 'Eastphalia as the Perfection of Westphalia', 17 Indiana Journal of Global Legal Studies (2010), 27 at 35.

89 G. Modelski, Long Cycles in World Politics (1987), 150.

90 J. Haslam, No Virtue Like Necessity - Realist Thought in International Relations Since Machiavelli (2002), 18-19.

91 M. Forsyth, 'The Tradition of International Law', in T. Nardin and D. Mapel, 23.

92 G. Modelski, Long Cycles in World Politics (1987), 144-45. 


\subsection{Corporate Relativism}

'Corporate relativism' is used here as a term to denote a doctrine that regards all human unions and associations as being placed on a somewhat similar, if at times only vaguely identified, normative and constitutional basis; and does not recognize the role of the sovereign State as the ultimate regulator of the legal life of all other unions and associations. It has been suggested that corporate relativism has its origins in Dante's emphasis on the human condition and on human associations that serve the needs of individuals and mankind. The final end of mankind is to realize the full potency of reason as the common end of individuals. ${ }^{93}$ Gierke suggests that man's identity is owed to his association with other men. Human associations connect past generations with current and future ones, and enable human development within a society. Human associations are organic in the sense of giving expression to human existence. ${ }^{94}$ Gierke emphasizes the German idea of freedom linked to the creation of human associations. All narrower subdivisions of a State conduct their own lives, and this cements State unity and human freedom. ${ }^{95}$ This approach is broadly compatible with the Aristotelian thesis that man is a social and political animal destined to live in a political community, but generalizes it to encompass all human associations.

Corporate relativism views the State as one of the links in the chain of institutions that, in their totality, express and serve the human condition. The initial origins of corporate relativism and their connection to both organic theory and the natural law and social contractarian theories have to do with medieval political processes involving various entities that were part of the Holy Roman Empire in their relations with that empire or papacy. But also, the core ideas of corporate relativism were developed by Beseler and Gierke in the examples of juridical persons under German private law: a multiplicity of institutions - such as corporations for private gain, charities, churches, social classes and State or municipal authorities - which differed from each other in terms of their arrangement or administration to enable them to represent relevant social interests, whether those of membership, property or other material or spiritual interests. Whether it was a corporation, a foundation (Stiftung), an institution (Anstalt) or the State itself (Fiskus), the sole reason behind their legal personality was to provide them with the capacity to participate in private legal relations, acquire property, enter into contracts and so on. ${ }^{96}$

\footnotetext{
93 Lewis, 852.

94 Gierke (n 3) (Bd I, 1868), 1 ('Was der Mensch ist, verdankt er der Vereinigung von Mensch und Mensch')

95 Id, 3.

96 G. Beseler, System des deutschen Privatrechts (Bd 1, 1873), 230-31.
} 
The principal thesis of corporate relativism is that the legal status, rights and obligations of an entity are produced by the social reality that underpins that entity. The transcendent and independent social reality behind it qualifies any human union or association not just as a private legal person, but also as a framework of authority and governance. Beseler's initial thesis was that the emergence of private law persons was also a public law affair. It was not the State which enabled the legal existence of these legal persons and asserted that they can be created without State will; for the State itself had not obtained its legal personality from the positive law-making act. ${ }^{97}$ Some corporations were older than the German State. ${ }^{98}$

Therefore, the legal basis of corporations was not their endowment by the State, but rather a more general association spirit of Germans (Associationsgeist der Deutschen). And where the State permitted the founding of corporations and supervised their activities, it merely exercised jus confirmandi, not jus constituendi. ${ }^{99}$ Beseler makes a plainly inter-disciplinary point here: socio-historical realities inform the essence of rights, status and authorities that exist and may be exercised as a matter of positive law. This implies the relativity of State legal order to the social values and traditions it is meant to serve.

Corporate association under German law was nothing other than a social community elevated, in its organic unity, to the status of a legal person (nichts anderes als das in seiner Lebenseinheit erkannte und zum Rechtssubjekt erhobene gemeine Wesen), ${ }^{100}$ involving the wholesale elevation of the social reality of human connections and relations to legal status.

For Gierke, human associations are social organisms with a head and organs (soziale Organismen mit Haupt und Gliedern), ${ }^{101}$ and the legal concept of a corporation is an abstraction that obtains its content from the reality of its social existence. ${ }^{102}$ Gierke suggests that 'moral person' is a name for the unity of individuals based on agreement or contract. But this concept has unconsciously enabled the expression of the fullness of social structures (Sozialgebilde) encompassing the range of unions, from family to corporations, local communities and States. ${ }^{103}$ For Gierke, the essence of a human association is its representation of a societal whole (das gesellschaftliche Ganze), which explains its legal personality and legal sphere. It has its internal side, which is capable of legal construction (eine einer rechtlichen

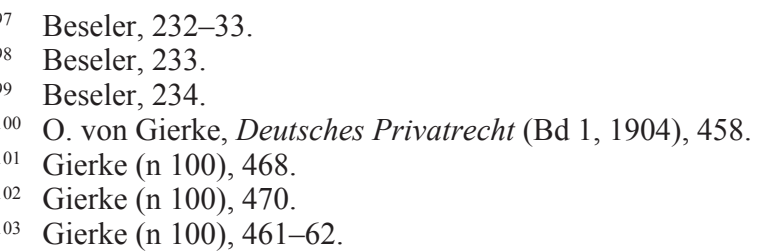


Aufgestaltung zugängliche Innerseite) ${ }^{104}$ but that internal side is merely a sociological reality, analogous to the biological reality of the individual, as the organic theory equates biological and social organisms.

Commenting on Beseler, Gierke admits that the real personality following from social unity is not only an issue to be resolved via private law, but also becomes a public law issue. ${ }^{105}$ And generally, it is inevitable that the multitude of units - from commercial guilds to towns, churches and so on - will bleed into public law, because corporate status becomes public law status and thus relates to the determination of the limits of the authority of the State itself.

So for Gierke, both a State and a private corporation can engage in private activities, such as disposing of property and entering into contracts; and public law activities, such as law making. The distinct position of the State with regard to other human associations can be denied by saying that they all - both State and non-State - give expression to relevant patterns of social and human conditions.

On plainly social contractarian terms, Gierke speaks of federalist theory, according to which all human associations have their specific life tasks (eigentümliche Lebensaufgaben) and legal essence independently granted to them under natural law, as though State and corporation had been born in the same manner or at the same time (naturrechtliche Ebenbürtigkeit der Körperschaft mit dem Staate). They are creatures of free social contracts and their internal corporate law is opposable to the State on its own footing. ${ }^{106}$ Depending on the individual interests of the day, corporations can be allies of the people against the State; or the State can become the ally of the people to protect them from the power of corporations. This exposes the lack of overall legitimacy under any shared and commonly applicable normative framework.

And Gierke criticizes Savigny and his followers for endorsing the idea of a public-private divide between States and other units; and for regarding the State alone as having organic essence, due to its transcendent metaphysics. ${ }^{107}$ For Gierke, all socially constituted private law units inherently obtain public law status - in essence adopting the same organic view of all corporations which he criticizes Savigny for using with regard to the State only. However, in the end, Gierke does accept that a human association obtains legal person-

104 Gierke (Bd 4, 1913) 411, 449.

105 Gierke (n 100) 466-67.

106 Gierke (n 3), 491-92, 521, 523.

107 O. von Gierke (n 100) (Bd 1, 1904), 467. Gierke reiterates the organic thesis that corporate communities (Gemeinwesen) emerge through processes of life (durch Lebensvorgänge) that belong to the world of historical facts, and owing to unconscious will processes; these life processes build the substratum of corporations, such as people, property, capital, land and territory; id, 483-85. 
ality from legal rules; and that the State, via its legislative will, can determine the conditions of existence of other associations. ${ }^{108}$ In essence, thus, corporate relativism is a gradated or relativized version of the representation of national spirit - whether Hegel's or Savigny's version - through public institutions; but it differs from the views of those authors in the sense that it asserts that social spirit is cumulatively and in parallel represented by a multiplicity of human associations that express the spirit of particular communities, religious denominations or professions. A shared premise with liberalism is that the State is presented as relative to its purposes as part of the wider transnational whole, and to the purposes of other entities or frameworks within that whole; all unions are building blocks within the transnational political order. This multiplicity of units' social identities and interests leads to the immediate and wholesale translation of all social interests into legal frameworks. Consequently, the existence of a single legal order with total legal regulatory authority to resolve underlying interest conflicts is impossible. Gierke accepts that elevating domestic constituents to the status of public legal personality requires that the legal personality of the State be dissolved into the multitude of public law persons. ${ }^{109}$ And even in democracies, this dilemma is still obvious, because as Rousseau has shown, democratic representation similarly presupposes the unity of a State order and its undivided sovereignty. ${ }^{110}$ However, the introduction of the concept of sovereignty makes the State specific in relation to other human associations that are also established by men to meet shared public or community interests. ${ }^{111}$ Corporate relativism asserted that corporations have their own self-existent public sphere. However, with the demise of this view, corporations were increasingly seen as analogous to individuals, who had a private law role only. ${ }^{112}$ Under this latter view, the State provides the framework for regulating the existence and activities of corporations.

And with the end of corporate relativism, it became possible to transform corporate theory from public law theory into private law theory. ${ }^{113}$

The positivist view is that all human associations and their legal status, rights and duties are products of State positive law. Historically, corporate relativism concerned what is ordinarily seen as interest-representation within the State, which from medieval times involved issues such as whether the State could abolish ancient city privileges, interfere with corporate property or tax church income. The argument to protect these interests from State interference

108 Gierke (n 100), 471-72.

109 See Gierke (n 3), 466.

110 See Gierke (n 3), 467.

111 Gierke (n 3), 285-86.

112 Gierke (n 82), 232-33, 239.

113 Gierke (n 3), 505. 
was that the relevant units possessed personality, status and privileges on some normative basis that the law of the State could not lawfully encroach upon. The plurality of legal orders was implied. Apart from cases which were based on the State's own recognition via laws, contracts and agreements, the ultimate allocation of authority as between units could be rationalized only by using natural law arguments articulating divine or secular reasons independent of State will - reasons to which no State law accorded any discrete significance.

As Poggi has eloquently described Gierke's theory, it:

suggests that the territorial ruler and the Stände make up the polity jointly, but as separate and mutually acknowledged political centers. Both constitute it, through their mutual agreement; but even during the agreement's duration they remain distinct, each exercising powers of its own, and differing in this from the "organs" of the mature, "unitary" modern state. ${ }^{114}$

And the units or estates (Stände) were seen to assert their own legal status as people's representatives, and to do so against the State and officials that were seen to represent the State. ${ }^{115}$ This is distinct from the representation of the interests of constituent units within national parliaments, which operate and determine the public good in their capacity of organs of a single State. Precisely for this reason, corporate relativism cannot be real within any State.

Bodin's theory was that other unions would be represented in parliaments and councils, through which the king could hear about their complaints and interests. Guilds and local governments were free and alterable creations of the sovereign State; their existence rested on State concession. ${ }^{116}$ The coherence of the State's regulatory function required the modification of guild rules:

this concern led the state to endorse, make uniform, and modify as needed the rules that over the previous few centuries guilds and other urban corporate bodies had autonomously and locally imposed upon commercial and productive pursuits: rules setting prices and standards for merchandise, specifying productive processes, regulating the training of apprentices, controlling competition and innovation. ${ }^{117}$

And this is how it has been since then pretty much everywhere. That which could exist within the context of the Holy Roman Empire - which was not the same as a consolidated State, properly so-called ${ }^{118}$ - could no longer be main-

114 Poggi, 48.

115 Gierke (n 3), 461.

116 As discussed in Gierke (n 3), 336.

117 Poggi, 78.

118 See further Chapter 4. 
tained once proper States had been consolidated in the space within which the Empire operated. As Poggi explains:

no nineteenth-century state is constituted and operates "dualistically," in Gierke's sense of the term, as the Ständestaat was... Mature modern states are intrinsically "monistic" and represent in this a return to the Roman tradition, whereby the princeps's power was derived from the will of the populus." 119

The unity of the State as the total legal order cannot coexist with any normative framework that endorses the idea of corporate relativism.

\section{NON-STATE ACTORS}

The status of non-State actors as units in international affairs could be asserted either in a wholesale manner, by using social contractarian theories; or by referring to individual instances from history when non-State entities have performed some international functions and then generalizing that experience to project their fuller, wholesale status. It is suggested that Hobbesian realism denies the existence on the international plane of actors other than States (eg, secondary associations, functional groups, economic associations, extended families), ignoring the fact that States are aggregations of persons and secondary organizations which are capable of independent political action. ${ }^{120}$ As Rosenau shows in a style that markedly resembles older corporate relativism doctrines, non-State actors have centralizing tendencies and obey instructions. They recognize the authority of their leaders, ${ }^{121}$ so they also develop a kind of autonomy and might thus be considered as a competing genus of a basic unit. Kleinschmidt suggests that the view that non-State actors are not participants in international affairs is a prejudice that unduly privileges the State's position. ${ }^{122}$

As ontology deals with being, we must examine which entities exist on the international plane and under which conditions - not just in terms of their actual and material existence, but also in terms of what their qualities are and how those qualities define their essence and relevance. We already saw that the concept of the sovereign State presupposes the suppression of any non-State public authority within the State's realm (eg, feudal, corporate or religious), or its incorporation within the State legal order. As shown, trading companies

119 G. Poggi, The Development of the Modern State: A Sociological Introduction (2001), 92-93.

120 Beitz, 37-38.

121 J. Rosenau, Turbulence in World Politics (1990), 110.

122 H. Kleinschmidt, 'War, Diplomacy and the Ethics of Self-Constraint in the Age of Grotius', in O. Asbach and P. Schröder, War, the State and International Law in Seventeenth-Century Europe (2003), 103 at 106-07. 
such as the East India Company were chartered by States and obtained from them the power to make treaties, build fortresses, appoint governors, administer justice and deploy armed forces ${ }^{123}$ - powers typically reserved to States and originating from State will and decision. Thus, these companies operated as organs and extensions of the State.

The international law view of State centrality is not just about its legal personality as a feature that could also, under certain conditions, be available to other units. It is additionally about the self-contained and autonomous nature of States as total legal orders with supremacy over their respective territory in a way that no other entity could have. It is on this account that public international law mandates States as basic units that can participate in international legal transactions, and also makes them responsible for any occurrences within their territories. In certain situations, wrongs perpetrated by non-State entities may be attributed to States; but there is no way to hold non-State entities responsible through international law, except by ways and means provided through agreement between States (eg, international criminal justice).

Non-State entities - whether terrorist networks or secessionist territorial units - have no existence on the international plane separate from the State; and the International Court of Justice has declined to regard secessionist authorities in Kosovo and their unilateral declaration of independence as possessing any relevance within the international legal system or affecting the rights of any State. ${ }^{124}$ Any transnational or transborder dealing with a non-State actor involves a dealing with the State within whose legal and sovereign territory the non-State actor is present and active. For instance, attacking a non-State terrorist network involves the invasion of the territory of the State in which that network is situated. War launched against a non-State actor becomes a war against the respective State. Any transboundary engagement of non-State actors by a foreign State engages the rights of the territorial State, regardless of the relationship between the foreign State and non-State actor. President Trump's appeal to Hong Kong dissenters to 'Defy Beijing' and NATO States' bombing of extremist groups in the Syrian territory both involved a violation of the territorial supremacy and integrity of the territorial State.

The principle that international law regulates the rights of States with regard to non-State actors, as opposed to regulating the rights of non-State actors directly, is also manifested in other areas. Companies active in transnational contexts have no rights arising directly under international law. Instead, State treatment of them is regulated by treaties, such as bilateral investment treaties.

123 Id, 109-10.

124 Accordance with international law of the unilateral declaration of independence in respect of Kosovo, General List No 141, Advisory Opinion of 22 July 2010. 
Any representation of individuals or companies before international judicial or quasi-judicial organs can take place only if the State whose conduct the litigation involves has acceded to treaties that provide for such adjudication. Non-governmental organizations assume important roles in multiple areas of international affairs; but when States are seen to have violated their rights or interests, these can be vindicated only through the intervention of other States, as seen in the Arctic Sunrise arbitration between the Netherlands and Russia.

On the whole, no non-State actor could compare to, or replace the relevance of, States as basic units endowed with territorial sovereignty and the final authority it carries with it. The State remains a sovereign and autonomous regulator of the life and activities of all units situated within its territory. It is on that account that the State appears as the primary subject of international law. Other units, such as international organizations, become international legal persons because States create them through treaties concluded between them.

\section{INTERNAL LEGITIMATION OF STATES}

The concept of internal legitimation is proposed here, and used in the broadest sense, as the sum of the means and processes through which a particular State justifies itself, perceives its own mission, formulates its policies and does anything else that its constitution enables it to do. Internal legitimation encompasses sociological, economic, ethical, psychological and constitutional interests and elements that shape or enable the formulation and expression of autonomous State will and interest. It encompasses the motives, reasons, interests and considerations that prompt the autonomous policy decisions made by States.

Internal legitimation is an inevitable analytical tool to operate with, because external legitimation of States is not feasible. There have been few attempts at external legitimation, such as those embodied in the 1991 European Community Guidelines on the recognition of States that emerged from the dissolution of the Socialist Federal Republic of Yugoslavia and the Soviet Union, which described the conditions under which the European Community would recognize them - for instance, the protection of human rights and minorities. But recognition does not create a State; other States' refusal to interact with a particular State because it does not fulfil particular perceived criteria of legitimacy has no bearing on the latter's existence as a State. Therefore, the valid international legal status of a lawfully established State presupposes only its own internal legitimation. International law prescribes no external requirements as to the constitutional forms of States, except with regard to cases in which States are formed through serious violation of international law, such as the annexation of territory from other States through aggressive war or ethnic 
cleansing of territory. ${ }^{125}$ Internal legitimation is individual to any particular State. There is no generally accepted pattern to determine what the national interest of States ought to be.

Internal legitimation of States shows not only that they are ontologically singular, but also the relationship between States and societies; how various aspects of international legitimation can illustrate the ways in which the State as a legal and political order is singular; and in what that singularity consists.

Beitz has suggested that:

states, unlike persons, lack the unity of consciousness and the rational will that constitute the identity of persons. If states are not simply voluntary associations, neither are they organic wholes with the unity and integrity that attaches to persons qua persons. ${ }^{126}$

Morgenthau has observed that:

The State is not a thing apart from society, but it is a product from society. The State is not the artificial creation of a constitutional convention, conceived in the image of some abstract principles of government and superimposed upon whatever society there might exist. ${ }^{127}$

The relationship between State and society illustrates that the ontological singularity of a State is only legal, not socio-political. The net socio-political value of a State on the domestic or international plane is determined by how the State is used by particular domestic constituents and how that use impacts on other domestic constituents or other States and their domestic constituents. The singularity of the State consists in its unique role to deal with and prioritize all competing domestic interests. As Soltau has explained:

The general will [of a State] is a fiction, which is itself based on another fiction, the concept of the State as a real 'person' with a 'will' of its own, a 'moral and collective body as Rousseau called it. ${ }^{128}$

On rather broad terms, Beitz suggests that 'a complete normative theory of international relations would require an account of domestic social justice'. ${ }^{129}$ But it is hardly feasible to deduce the relevance of States as singular units

125 See, on the creation and recognition of States overall, A. Orakhelashvili, Akehurst's Modern Introduction to International Law ( $8^{\text {th }}$ ed, 2018), Chapter 5.

126 Beitz, 81.

127 H. Morgenthau, Politics among Nations (1948), 398.

128 R.H. Soltau, An Introduction to Politics (1951), 100.

129 Beitz, 122. 
in international affairs by reference to their internal legitimations, which are unique to each State.

Krasner observes that a State can be weaker or stronger on the international scene, depending on how it deals with domestic constituents' interests. Excluding some interests from consideration can enhance a State's strength internationally and enable it to act more monolithically. ${ }^{130}$ By contrast, a government might itself seek the involvement of sectoral interests to enhance its own policy. As Hyam has explained:

Even when government appears to have been responding to popular pressure to act in a particular way, only a little research will usually expose the error. Thus in the case of the retention of Uganda in 1894, we now know that Rosebery's Cabinet, far from responding to missionary demands, had itself asked missionaries to whip up a campaign in its favour, in support of a decision already taken on strategic grounds (to protect the headwaters of the Nile).

Overall, nineteenth century British foreign policy seems to have subordinated trade to strategic interests and calculations..$^{131}$

At times, the complexity of the relationship between politics and the economy has been obscured or overlooked. Research conducted in the early 1990s regarding Japan's economic expansion in the Pacific revealed this problem. Political scientists found that by cooperating with Japanese government agencies, Japanese companies 'were consciously fashioning a regional division of labor composed of highly integrated production and distribution networks centered on the Japanese home economy'. Economists, concentrating on the ordinary nature of trade flows and measurable economic data, were unable to sustain the thesis that the Japanese state and corporations were attempting to create an exclusive economic sphere in Pacific Asia. Instead, they suggested that this could all be explained by the dynamics of market forces. ${ }^{132}$

Interest-representation is ordinarily conducted in the parliamentary and legislative contexts. Still, every constitution provides the executive branch of the government with relative freedom to act in foreign relations in pursuit of the dominantly perceived national interest. This provides a route for the substantiality or individuality of the State, its interests, its preferred vision of international affairs or international public goods to be asserted in the realm of international affairs. Constitutional discretion allotted to the executive branch of the government (eg, royal prerogative in the United Kingdom) also operates

130 Cited in R.W. Jackman, Power without Force: The Political Capacity of Nation-States (1993), 68.

131 R. Hyam, 'The Primacy of Geopolitics: The Dynamics of British Imperial Policy, 1763-1963', 27 The Journal of Imperial and Commonwealth History (1999), 27 at 30.

132 R. Gilpin, Global Political Economy (2001), 32. 
to restrict the influence of public opinion on foreign affairs. Still, such authority is one to choose between conflicting policies in the name of the State, as any other public authority is.

Herz suggests that, on its face, the national interest is essentially national and distinguishes it from crusading policies, to which grand strategies ultimately amount. ${ }^{133}$ Lasson has suggested that peace between States is assured more if States are organized so that those in charge pursue genuine State interests, rather than their own. ${ }^{134}$ However, no fixed concept of transcendent State interest can be clearly demarcated from the group or individual interests that influence decision making by States. This is precisely what informs the autonomy of a State. Historically, the relationship between State and sectoral interests has been reflected in various constitutional contexts. It is debatable whether raison d'état refers to the interests of a monarch or the entire nation. In reality, it is only an analytical description of the process of how the State deals with conflicting social interests and prioritizes some of them over others. Often, social forces and interest groups will at least attempt to appropriate this seemingly discrete State reason, determine its content and use it to their own advantage. Whether this happens through the whispers of the favourites of a medieval monarch or through lobbying in modern parliamentary democracies is not of crucial importance.

Fukuyama has explained how this dynamic can go in different directions:

This state, usually embodied in a professional permanent bureaucracy, at times has to lean against the popular will because it has a clearer view of the common interest of the nation. The Lockean liberal view of the state that prevails in the United States, by contrast, sees no public interest apart from the aggregated interests of the individuals who make up a society. The state is the servant of the people and has no views of the common interest apart from what is democratically ratified by them... democratic publics can delegate executive authority to the state for certain critical decisions, but the state retains no fundamental autonomy. ${ }^{135}$

Allott has also referred to US law as 'the central instrument of the self-constituting of American society'. ${ }^{136}$

However, Fukuyama's reference to the Lockean liberal view representation by the State of society assumes a monolithic unity of social interests in any

133 J.H. Herz, 'Political Realism Revisited', 25 International Studies Quarterly (1981), 182 at $191-92$.

134 Lasson, 96, 100.

135 F. Fukuyama, State-Building, Governance and World Order in $21^{\text {st }}$ Century (2004), 110.

136 Cited in S.V. Scott, International Law, US Power: the United States' Quest for Legal Security (2012), 9ff. 
particular country; and also that public opinion is mostly, if not invariably, uniform. On more real terms, the national interest should be defined as whatever interest the State has decided to adopt as the foundation of its policies.

Grotius was clear that 'The particular interests, with which he who governs concerns himself, are either exclusively public interests, or private interests which have a relation to public interests'. ${ }^{137}$ Herz queried: 'What is that “national" in national interest?'; and added that 'subnational interests, of business, ethnic, or religious groups, and so forth, may and do influence a nation's foreign policy stands'. Speaking predominantly of totalitarian regimes - but in a way that can be applied beyond them - Herz wondered whether one could:

meaningfully speak of national interest where majorities in a unit ... may be quite uninterested in the defense of their unit as long as it is under such control? The assumption that the rational actor, that is, the official or officials formally representing a state, can be considered as acting in the common interest of that state, becomes doubtful. ${ }^{138}$

It has been clarified that there is no such thing as a single national interest. Instead, there is a marked plurality of groups and individuals within States, with diverse values, preferences and interests. ${ }^{139}$ Bernard was clear that:

national interests are by no means so simple and enduring, so plain and easy to apprehend and pursue, as it was formerly the fashion to assume. There are cross interests, competing interests, occasional and ephemeral interests - there are apparent interests which are not really such, but are purely speculative and imaginary. Even if we could be sure we knew the true interests of a particular State, we can by no means be sure that it will act on them. ${ }^{140}$

And most importantly, each policy has its partisans within the relevant State, ${ }^{141}$ which will contribute to the determination of patterns of relations that States conduct with each other. Domestic groups that gain the upper hand will undoubtedly influence foreign policies. And Bernard is clear that 'it [is] a matter of almost incessant speculation whether the controlling or the disturbing forces will get the upper hand'. ${ }^{142}$ Autonomous decisions of a State are not the same as decisions one considers to be sound or beneficial. In many

137 Grotius, 102.

138 J.H. Herz, 'Political Realism Revisited', 25 International Studies Quarterly (1981), 182 at 189.

139 S. Oeter, 'Conflicting Norms, Values and Interests: A Perspective from Legal Academia', 33 EIA (2019), 57 at 63.

140 Bernard, 79.

141 Bernard, 81.

142 Bernard, 83. 
societies, no uniform view can be identified as to whether invading another country or allowing foreign production into the country that would harm the nation's own industry or agriculture truly reflects the will of the people. Still, the State makes these decisions; and in doing so, it listens to some domestic constituents and ignores the interests of others.

Even in the eighteenth century, when the difference between the interests of a monarch and the State interest was not as clear-cut as it is today, 'George II's concern for Hanover, for example, was regarded as the product of a proprietorial interest at variance with the interests of Britain'. ${ }^{143}$ This restrained the political manoeuvrability of the British government in Europe - especially in relation to Prussia, which threatened to invade Hanover unless Britain desisted from certain policies aimed at securing equilibrium of power in Europe. Thus, a sectoral interest essentially constituted and controlled the dynamics of the national interest. Other cases of State governments being manipulated, bought off or coerced are not unheard of. A political regime's concern for its survival often leads to the adoption of national policies that do not adequately protect the interests of domestic constituents.

The role of the national constitution as the expression of the Hegelian substantiality and individuality of States is the same in all States. Whether aggressive war against another State is commenced on the whim of autocrats or by considered decision of democratic and limited governments, politically it is an autonomous State action and legally it is an internationally wrongful act.

Kissinger suggested that the domestic nature of States influences their perception of acceptable patterns of international relations. ${ }^{144}$ Kant maintained that democracies are less likely to wage wars, at any rate against one another. Yet as Bernard has clarified:

the temptation which may beset a prince or statesman to engage in foreign wars for the sake of diverting public attention and assuaging discontent; the temptationcommon however to both free and monarchical Governments, though operating in different ways - to interfere in the domestic affairs of other countries; the temptation to draw questions of foreign policy into the arena of party strife... forms of government are not in this matter quite so material as they have been thought to be. ${ }^{145}$

A century and half later, this could not be more true. Interests within the State invariably diverge, but all States are identical in their singularity.

143 P.F. Butler, 'Legitimacy in a States-System: Vattel's Law of Nations', in M. Donelan (ed), Reason of State (1978), 45 at 59.

144 H. Kissinger, 'Domestic Structure and Foreign Policy', 95 Daedalus (1966), 503.

145 Bernard, 104-05. 


\section{CONCLUSION}

This chapter has demonstrated the core importance of States as basic units in international affairs. The core element of State autonomy is one on which both the creation of international rights, obligation and authority, and the ultimate dynamics of power politics, crucially depend. The essence of the ontological singularity of States as basic units dispels the doubts that contractarian, liberal and other theories have raised against the centrality of the State. Hence, the rest of the analysis in this book will be conducted on the premise that the State is a central and key basic unit in international affairs. 